\title{
Social and Neoliberal Revolutions in the United States
}

The legal revolutions depicted by Berman involve a reinvestment in meritocratic scholarly capital-in opposition to conservative social and political capital-as well as strategic alliances with emerging political or social groups disposed to embed their movements in the law. In the United States, lawyer-brokers found ways to connect with international scholarly capital from Europe, huge corporations, social movements, and a new reformist politics. They upgraded legal scholarship and legal argument to serve and better legitimate the emerging coalitions, and they brought new and more meritocratic blood into the legal profession. The same set of events reinforced the hierarchies of the legal field with the rise of new professional organizations, more stringent educational standards, and challenges to the law schools that served immigrants and others not sharing the White Anglo-Saxon Protestant characteristics of New York's elite lawyers and their counterparts in other major cities.

A highly stratified market in legal education emerged, defined mainly by the elite schools' connections to the "upper hemisphere" of corporate law firms. Market competition reinforced hierarchies, since those who had social advantage were far more likely to gain entrance to leading law schools, but the relatively meritocratic competition between laws schools and within those schools also helped make the US legal field more responsive and porous than the European legal fields with respect to economic, social, and political change. That adaptability is apparent in relation to the various challenges and responses of the twentieth century-from the New Deal to the civil rights era to deregulation and global neoliberalism. There was a succession of relative busts and booms in the United States that saw the elite of the profession further open up, legal scholarship play an increasingly important role, and law professors gain a stronger position than they had held in the early twentieth century, when they were merely subordinate teachers and compilers 
of laws made by notable lawyers and judges. The booms and busts were less a function of diminished professional markets than of challenges or threats to the symbolic capital accumulated around the law.

\section{THE LEGAL REALIST "COUP": FROM TEACHERS \\ AND COMPILERS OF THE LAW TO FULL PROFESSORS AS ADVISERS FOR REFORMIST RULERS}

The Great Depression and the New Deal brought a serious challenge to the established hierarchies of the legal field in the United States. At first, the corporate law firms on Wall Street echoed their clients' ambiguous relationship to the New Deal (Shamir 1995). They recognized that a crisis was at hand and acknowledged the need for bold action. But after a few years, client opposition to new regulations strengthened and corporate law firms exceeded their clients in their opposition. They saw administrative agencies and European-influenced notions about legal bureaucrats being independent experts as threats to their position, and they became more and more identified with resistance to the New Deal. Indeed, the agencies initially were a threat to lawyers, who, during the 1930s, were in danger of being excluded from the New Deal and of losing the access to courts where they could challenge administrative policies. Wall Street corporate law firms and their analogues in major cities had become too complacent. They had prospered through their tight relations with the major corporations and through practices that were conservative both politically and relative to the once forwardthinking expertise they employed. Now, during a severe economic depression, new social groups and the emerging social sciences were challenging the legal and economic establishment.

In the relatively open (as compared to Europe) US context, there were opportunities for entrepreneurial lawyers to forge strategic alliances both to push against established law and, ultimately, to rebuild the credibility of lawyers and the law from within. The scholarly challengers, identified with the legal realists especially at Yale and Columbia, denounced a profession that had become "the obsequious servant of business, tainted with the morals and manners of the market place" (Shamir 1995: 148). Through key brokers such as Harvard's Felix Frankfurter, lawyers placed their expertise in the service of the new bureaucracies of the New Deal by promoting "socially informed law" through "enlightened legislation" capable of solving social problems that were "too complex, too difficult to be handled by the average judge" (150). The legal realists thus took on the elite corporate bar and the appellate judiciary that supported its positions to promote an upgraded expertise that arguably needed to go around the law. At the same time, as Shamir rightly emphasizes, legal realism was a "collective mobility" project for legal academics who were at the time still relatively marginal in relation to the most powerful corporate attorneys and leading judges. 
The academic challengers attacked the idea that the law was neutral and predictable, and they criticized the courts and the conservative legal establishment for resisting New Deal reforms. Law professors formed alliances with the emerging social science disciplines (Schlegel 1995) with the goal of applying the law to resolve social problems and enhancing the credibility of legal academic scholarship.

Key to all this was the meritocratic component of the movement as embodied by the New Deal and legal realism. Shamir notes that the movement brought Jews, Catholics, and the children of immigrants into legal positions to which they had previously lacked access (Shamir 1995; Dinnerstein 1983; Auerbach 1976). Roosevelt once declared: "Dig me up fifteen or twenty youthful Abraham Lincolns from Manhattan and the Bronx to choose from. They must be liberal from belief and not by lip service. They must have an inherent contempt both for the John W. Davises and Max Steuers [conservative corporate attorneys]. They must know what life in a tenement means" (Auerbach 1976). Accordingly, while "young Jewish attorneys in the 1930's" found few career opportunities in law firms, the New Deal was relatively open to them: it "needed legal talent, and Jewish lawyers needed the jobs that the New Deal provided" (Dinnerstein 1983: 464). To be sure, Jewish lawyers did not gain appointments to many judgeships or cabinet positions, but advisers like Benjamin Cohen and Thomas Corcoran, one Jewish and the other Irish Catholic - both Harvard graduates recruited by their former professor, Felix Frankfurter-were among the most influential lawyers in the New Deal (Dinnerstein 1983).

This challenge from within the legal field opened up places for a new generation of meritocratic lawyers and law professors, who would turn out to be central to the New Deal. Thus, the rise of the activist state in the United States was not accomplished by pushing lawyers aside, notwithstanding the complacency that had led to the political depreciation of the Wall Street elite. Instead, aided by a system of administrative law that gave the courts a significant role, lawyers again thrived within the system. This revitalized the legal hierarchy and buttressed the centrality of the corporate bar. One aspect of this was a clear increase in the status of the elite law professors. As Shamir (1995) writes, "legal academics offered a scientific rationale for the administration's policies, countered the bar's and the judiciary's resistance, and contributed their services to the governmental state apparatus. In return, law professors reached positions of influence and prestige that they had never enjoyed before" (152). This also led to a strengthening of existing hierarchies. As the professors and their disciples rose within the existing fields of power, the critical bite of legal realism diminished, as did any hints of a new administrative elite consistent with that realism (Schlegel 1995; Shamir 1995). The incentives to gain power and credibility by taking the social sciences seriously likewise diminished considerably. By the 1950s, with the advent of the Cold War, the new politics and the new social sciences had been converted into the legal establishment, with its accompanying programs of the new "legal process school." 
Along the way, the corporate elite was revitalized through the rise of Washington law firms that had emerged from legal realism and the New Deal, epitomized by Arnold, Fortas, and Porter. These firms reestablished the legitimation strategy earlier developed by the Wall Street firms-a combination of public service and corporate representation, symbolized now by the revolving door in Washington, D.C., between the corporate law firms and the federal regulatory agencies and departments. These Washington firms too became more open. They recruited Jews and others who had not been welcome on Wall Street. As Auerbach notes, "the battleground was at the apex, where old and new elites clashed. When the dust kicked up by their professional rivalry finally settled, the old structure was greatly strengthened by its newest inhabitants, who were, by their presence, its newest defenders. . . . In service to power, lawyers made government by a legal elite the culmination of New Deal liberalism" (Auerbach 1976: loc. 4744).

With the increased prestige of the law professors, the place for academic "legal theory" grew substantially. But this did not change the hierarchy of power within the US legal field. Indeed, paradoxically, the emergence of the Washington law firms reinforced the strength and legitimacy of the corporate practitioners close to the state and to economic power. The legal academic market thrived through the alliances forged between the legal realists and those who had ascended into the government through the New Deal. They were able to criticize the legal establishment-especially the Wall Street lawyers-as overly formal and conservative; meanwhile, their success enabled them to rebuild and retool that establishment for an era in which the state and state regulation were increasing in importance.

\section{THE CHALLENGE OF THE $1960 \mathrm{~S}$}

The background for the challenges of the 196os and later was the success of the coalition that governed after the New Deal. The Kennedy administration marked the apotheosis in power of the so-called foreign policy establishment (FPE), a group descending from lawyers like Elihu Root (see the previous chapter) that included a strong cohort of investment bankers as well as corporate lawyers. The history of the FPE and the Council on Foreign Relations, which came to monopolize the key positions in foreign policy from the 1940s through the 1960s, has been well-documented (e.g., Bird 1992; 1998). The elite circles linked to the FPE during those decades controlled the Ivy League universities, the major philanthropic foundations, the State Department, the CIA, and the major corporate law firms and investment banks. Geoffrey Kabaservice (2004) referred to the network around the FPE in the 1960 s as the "liberal establishment."

A key individual was McGeorge Bundy, once a very young Dean of the Faculty of Arts and Sciences at Harvard. He became Kennedy's National Security Advisor in 1961 and remained in that post until 1966, when he left amid controversy 
over the Vietnam War to become president of the Ford Foundation, where he remained until 1979. Bundy was not himself a lawyer, but his father and brother were, and he was quite close to the elite legal world. Kabaservice's book on the liberal establishment focuses on McGeorge Bundy, Kingman Brewster, Cyrus Vance, Elliot Richardson, John Lindsay, and Paul Moore. Brewster, Lindsay, Richardson, and Vance were all corporate lawyers at one time or another. What united this social and academic elite was the belief that the establishment in its own interest had to expand opportunities for new groups in the postwar era. They served the government and brought together the resources of the elite universities, exemplified by Bundy's ties to Harvard and Brewster's presidency of Yale; the metropolis, with New York City Mayor John Lindsay in particular; the foundations, including Bundy at the Ford Foundation; and the corporate law firms, with Cyrus Vance of Simpson Thatcher in particular (Vance also served on the boards of Yale and the Ford Foundation).

The patrician social profile of this group helps explain the challenges that later emerged. As noted by Richard Barnet in Roots of War (1971), a book that laid out this challenge, "the temporary civilian managers who come to Washington to run America's wars and preparation for wars, the national security managers, were so like one another in occupation, religion, style, and social status that, apart from a few Washington lawyers, Texans, and mavericks, it was possible to locate the offices of all of them within fifteen city blocks in New York, Boston, and Detroit. Most of their biographies in Who's Who read like minor variations on a single theme-wealthy parents, Ivy-League education, leading law firm or bank" (49).

The politics of the academic investment that was central to the legitimacy of this Eastern establishment contributed to the questioning of the social homogeneity and implicit consensus that provided its strength. Ivy League colleges in the years after the Second World War broadened (in relative terms) their recruitment policies. As noted earlier, members of the liberal establishment sought to enhance the legitimacy of that establishment by opening it up to those who had been excluded (Kaboservice 2004). These new arrivals, however, were often less disposed to accept the prevailing orthodoxy and hierarchy. Unlike the preceding generation of so-called wise men, the newcomers had not, as a rule, passed through the prep schools of Groton, Lawrence, St. Paul's, Andover, or Exeter. They lacked the shared background that had allowed the preceding generation to acquire very early the social habitus that was at the root of their moderate political vision.

There was therefore a pronounced contest internal to the system. It emanated from the newcomers and the generation they represented. The critique by Richard Barnet, a graduate of Harvard and Harvard Law School and at one time an assistant to John J. McCloy, the so-called "Chairman of the Establishment" (Bird 1992), reflects the world view of this generation. The newcomers were quite conscious of the limits of the meritocratic ideology that formed part of their own identity. Tensions were found especially in the institutions whose task was to bring combat 
to the terrain of ideas, precisely because those institutions were situated where the field of power met that of learning.

The Vietnam War divided the liberal establishment between hawks who supported the war and doves who were against it - a split that enabled the election of Richard Nixon in 1968. More fundamentally, many among the younger generation who opposed the Vietnam War became radicalized and challenged the legitimacy of the liberal establishment and its leaders in the corporate bar. They also began to question the Washington bar, whose members had long occupied positions as both servants of business and so-called wise men deemed capable of governing in the public interest. They were perceived as hawks and as too close to business. The corporate law firms' links with the elite campuses were threatened by this loss of legitimacy and by movements on the left that attacked big business and those who served it. At the same time, the civil rights movement brought into question the moderate tactics of the corporate lawyer-statespersons. As we shall see, the corporate legal statespersons at the top of the profession were seen as increasingly out of touch with American society.

When given access to elite institutions such as the leading law firms, many in the new generation did not feel in sync with those in power. In addition, as the path from the Ivy League colleges to the institutions of Wall Street and Washington, D.C., became more crowded, the new generation had to invest in new spaces of professional practice. One set of opportunities was connected to the expansion of such areas as developmental assistance, including the Peace Corps and programs launched in the name of the Alliance for Progress in the early 1960s. Another set of opportunities was linked to the many projects of social integration that came into being under John F. Kennedy, later to be identified with the Great Society of President Lyndon Johnson. The War on Poverty encouraged many young idealist lawyers to work in programs offering legal services for the poor, and lawyers became more aggressively involved in the civil rights movement. Indeed, the civil rights movement is one example of how the generational divide surfaced.

As the civil rights movement heated up in the 1960s, elite lawyers and their allies in the federal government spearheaded a number of legislative reforms to try to get in front of these civil rights and anti-poverty issues. It was difficult to contain the civil rights struggle in the South, and it quickly became a challenge for the Kennedy administration. Thomas Hilbink writes that in the view of many activists, "the Kennedy administration proved not to have the moral commitment to the goals of civil rights as activists believed" (Hilbink 2006: 75). In fact, the elite lawyers around Kennedy were simply working according to the usual strategy of the moderate reformers, and that strategy was unable to accommodate the political turbulence. Hilbink's exceptional detail on the generational clash provides a unique vantage point on this process.

As Hilbink suggests, it is indicative that the lawyer selected to head the Civil Rights Division under Kennedy was Burke Marshall, a partner in the Washington, 
D.C., corporate law firm of Covington and Burling-"a first-class lawyer who would do the job in a technically proficient way" (76), according to Byron White, then the Deputy Attorney General. The administration inevitably looked to elite corporate law firms for people with the stature and leadership to manage difficult problems at home and abroad. As Hilbink shows, Marshall and others in the administration were Ivy League gentlemen who wanted to persuade reasonable individuals in the South-their presumed counterparts - to open up the system to African Americans. They "assumed that the system maintaining their status was basically sound," but by then both sides of the civil rights struggle were pushing the bounds of civility (78). The advisers followed the strategy of trying to gradually expand participation, but this moderate strategy was not working in the South.

The "rule of law" by which this elite defined itself was being threatened by southern resistance and civil rights activism, and elite corporate lawyers pushed Kennedy to do more to handle the situation. The White House responded with an invitation to this corporate elite and some others to assess what could be done through law. The gathering brought 250 distinguished lawyers-"very elegant lawyers" - but notably excluded the leftist National Lawyers Guild. Kennedy called for the help of elite lawyers in keeping everything "calm" (78). Some of those there, including Father Robert Drinan, then the Dean of Boston College Law School and more on the side of activism, felt that the administration was too tepid in its commitment to civil rights enforcement.

The administration then formed a committee-the Lawyers Committee for Civil Rights Under Law (LCCRUL) — chaired by Bernard Segal, later president of the ABA and a corporate lawyer in Philadelphia, and Harrison Tweed, former president of the National Legal Aid and Defenders Association (NLADA), chair of the American Law Institute, and named partner in the Wall Street firm Milbank and Tweed. This committee was a prestigious group dominated by corporate lawyers known also for their public service. The natural order in their social world was that the lawyers would help solve the problem and at the same time reinforce the ideal of lawyer-statespersons serving both their clients and the public good.

When the famous Freedom Summer arrived in 1964, it presented a challenge to the players in this domain. The corporate lawyer-dominated LCCRUL opted to bring some volunteers to the South with a narrow mandate-to represent ministers and to try to persuade white southern lawyers to represent individuals arrested for civil rights activities. The more activist side of the liberal establishment went further. According to Hilbink, the NAACP resisted the participation of volunteers from outside-mainly to protect their own turf; meanwhile, the America Civil Liberties Union took an interest largely to "pre-empt" the Lawyers Guild (101). Soon after, the ACLU teamed up with the American Jewish Congress, the American Jewish Committee, the Congress of Racial Equality, Father Drinan, and others to coordinate activist lawyers and students who would be going to the South. Terming their alliance the Lawyers Constitutional Defense Committee 
(LCDC), they sought to connect more to the new-generation activists. They recognized that genteel strategies were not working. But, as noted, they also sought to keep the Lawyers Guild at a distance.

After the Freedom Summer, the groups that had provided assistance recognized the desirability of a more permanent presence in the South. Making the case to foundations, the more activist LCDC emphasized its connections as well as its ability to "appreciate the political purposes and strategy of the operative civil rights organizations" (131). The more establishment Lawyers Committee (LCCRUL), by contrast, emphasized its connections to the federal government and its elite professional profile. When it came time to choose which group ultimately to support in 1967, the Ford Foundation opted only for the Lawyers Committee.

The story Hilbink tells provides detail on how the combination of professional prestige, connections to corporate clients, and connections to the major philanthropic foundations shaped the Kennedy administration's approach to the civil rights struggle. The administration naturally turned to its legal counterparts from the liberal establishment's social world. The elite lawyers they turned to also, not surprisingly, did not want to work with and provide legitimacy to those whom they perceived as outside the mainstream, in particular the National Lawyers Guild. The threat to the hierarchy in public service was also a threat to the position of the corporate lawyer-statespersons.

With respect to the War on Poverty and civil legal aid, the second director of the Legal Services Program, Earl Johnson, Jr., recognized that the elite law firms were being questioned and sought to build on that development. There was an opening, he saw, for idealistic law students who were not radicals but who also did not want to work in corporate law. Johnson promoted Reginald Heber Smith fellowships to try to recruit "the top rank of graduating law students," former federal judicial clerks, and young corporate lawyers, with the goal of creating an "elite corps of lawyers" who would make lawyers key to the War on Poverty. Johnson sought to create an outlet for "a group of talented young lawyers rejecting the rhetoric of revolution and signing up for a low-paying job that sought only peaceful, orderly change through established institutions" (Johnson 2013: 149). Legal services lawyers in the mid-1960s did indeed take up the call for legal activism, especially through test cases. Their legal activism, even if through the system, faced strong resistance at the end of the decade as conservatives began to fight back under Richard Nixon (Hilbink 2006).

The challenge from the left was also still there. Hilbink (2006) points out that notwithstanding the progressive activities of the relatively elite bar in the 1960 s and 70s, "radical lawyering" that directly challenged the elite institutions was thriving. According to Johnson, leftist lawyers told those who joined the Reginald Heber Smith program that legal services could only "mitigate" conditions that required more revolutionary action. The most radical lawyers had very little faith in law and the legal system. They did not believe that solutions to social problems could come 
through the moderate legal reforms favored by the liberal establishment-in fact, law was considered a major part of the problem. The lure of radical lawyering (or just radical action) further undermined the position of law and its hierarchiescorporate lawyers, elite law graduates-in the US state and economy. More fundamentally, the credibility of corporate lawyer-statespersons was threatened-their social capital was depreciating.

The story Hilbink (2006) tells of the creation of public interest law early in the 1970 fits this account. The crisis felt by Washington law firms in particular was central to the emergence of public interest law as a solution to the more general problems facing the liberal establishment and the elite corporate lawyers within it. Ralph Nader's activities on behalf of consumers drew many elite law graduates toward activism against corporate misconduct, and Nader made clear that Washington lawyers were at the core of the problem. The revolving door between Washington regulators and corporate lawyers-once a marker of public servicewas characterized in the environment of the late 1960s as illegitimate. The classic ideal, that corporate lawyers gained stature and credibility by helping write and enforce rules that to some extent moderated and at the same time legitimated the power of their clients, was not persuasive to the public, to elite law students, or even to a number of the associates in the leading corporate law firms. It was not enough, for example, that Lloyd Cutler, who represented the auto and drug industries through Wilmer, Cutler, and Pickering, was on the board of the Lawyers Committee for Civil Rights Under Law, nor that he had served numerous presidents. The critical climate was especially strong since the leaders of the firms under attack were classic New Deal liberals, including the partners of Arnold and Porter. In such a climate, the attractiveness of law school-and corporate law as an elite career-for talented and ambitious idealists was under threat.

The public interest lawyers who emerged in this era, according to Hilbink, represented "a cross-section of those typically found in the upper echelons of the American bar. They were the establishment" (309). In fact, they had the establishment credentials of elite law schools, judicial clerkships, and corporate law firm positions, but, as in the New Deal, they were not the WASP social establishment of the classic corporate legal elite and its accompanying circles. Charles Halpern, as profiled by Hilbink, exemplifies the change that took place in the appeal of the corporate lawyer-statesperson role. Halpern grew up in Buffalo, New York. He is Jewish, and his father was a law professor and judge (Halpern 2017). Halpern was relatively apolitical as an undergraduate at Harvard. He attended Yale Law School, went to work at Arnold and Porter after a federal clerkship, and imagined "a career of working at a law firm, doing pro bono work, and taking stints in government" (Hilbink 2006: 311). He embodied meritocratic success. His ambitions also reveal that he had internalized the hierarchies and incentives that put US corporate lawyers at the top of the legal field and brought them economic rewards, respect, and influence over public policy. He was looking to become an elite lawyer-statesperson. 
In the late 1960s, however, Halpern began to feel increasingly attracted to activism and disillusioned with his work for Arnold and Porter, which included representing big tobacco. The career for which he had prepared himself had depreciated in value. He also did not find a natural fit at Arnold and Porter. As he wrote in his autobiography, "I had no skill at schmoozing with general counsels and chief executives in the clubhouse after a round of golf. I couldn't imagine bringing new corporate business into the firm. Ultimately, that's what the firm was all about. Lawyers who lacked that skill, no matter how brilliant, stalled partway up the ladder. The meritocracy that seemed to flourish in the law schools and in the first round of law firm hiring was replaced by a different meritocracy, one that was explicitly attuned to attracting corporate clients" (Halpern 2008: loc. 714). Working with others who shared his position, he came up with a proposal for foundation funding of a Center for Law and Social Policy.

Another key individual profiled by Hilbink, Carlyle Hall Jr., began Harvard Law School in 1963. After graduating, he took a detour, traveling to the Sudan and Uganda to do "law and development" work. Upon his return in 1969, he went to work for O’Melveny and Myers in Los Angeles, attracted by Warren Christopher, the most important partner and one who had "long combined private lawyering with public service" (315). Hall too was following the internalized program of the elite lawyer-statesperson. But he too became disillusioned with corporate practice, again reflecting the depreciation at that time of the traditional path to the elite. He joined with three others from O'Melveny to work on a proposal to the Ford Foundation for the Center for Law in the Public Interest.

These personal histories, in Hilbink's words, “demonstrate the connection of public interest lawyering to both the late 1960 s and the movements that influenced and preceded it" (316). The connection to activism is evident, and it helped make corporate lawyers seem quite conservative. Both Halpern and Hall had been on a track to mimic the lawyer-statesperson roles they identified with the Washington, D.C., corporate elite represented by Arnold and Porter (in Halpern's case) and Warren Christopher (in Hall's case). As a new generation less endowed with social capital, they may have felt less at home in the corporate firms than they expected; they also were invested more deeply in the idealism they had thought accompanied the elite lawyer role.

The liberal establishment, including the elite universities, the Ford Foundation, and leading corporate law firms, had sought to handle the unrest of the 196os through a partnership with the federal government as it promoted moderate changes in public policy. The changes sought to bring in groups that had been excluded from the benefits of American prosperity. The election of 1968-which divided the establishment over Vietnam-had led to Nixon's election, and problems of social unrest remained strong. The Ford Foundation and others sought to maintain their influence, bring progress that would curb the social unrest, and restore faith in the rule of law. Also implicit in the Ford agenda was a sense of 
the normal as one in which the elite lawyers were at the top of the legal hierarchy and the economic and political system that allowed the clients of those lawyers to thrive was viewed as legitimate. McGeorge Bundy, the president of the Ford Foundation, was a strong believer in legal strategies as a way to steer a middle ground between the left and the right.

Halpern sought out the Ford Foundation at the same time that individuals there, notably Sanford Jaffe and Gordon Harrison, were looking for ways to retool the legal profession in a time of political crisis. Harrison was then already in contact with a group of Yale students seeking to create an organization to address environmental legal issues. Harrison helped link the students to Whitney North Seymour, a prominent Wall Street lawyer with experience in environmental law. The moral enterpreneurs, the elite law schools, the liberal establishment, and corporate lawyers were in the process of coming together. According to Laura Kalman, Yale law professors Charles Reich and Boris Bittker helped facilitate a "forced marriage" between corporate lawyers and the Yale idealists (Kalman 2005: 223). As the Ford Foundation moved toward a new program, it naturally approached trusted advisers, such as David Peck of Sullivan and Cromwell, who favored the initiative. In March 1970, Jaffe and Harrison brought a proposal to the board of the Ford Foundation titled "Advocacy, Law, and the Public Interest."

The price of gaining the support of the Ford Foundation was a forced marriage with the members of the liberal establishment open to this reform. The program contemplated a very close relationship between progressive members of the corporate bar and public interest law. Jaffe and Harrison sought "the best professional judgment available concerning professional integrity, quality, and experience of individual and group applicants" (Hilbink 2006: 332). That meant the elite corporate bar. In particular, Jaffe put together a Public Interest Advisory Committee to "insure that the highest standards of prudence and professionalism characterize our efforts in this field" (333). The four members of the committee were William Gossett, former partner of Hughes, Hubbard and Reed (and married to the daughter of Charles Evans Hughes), ABA president, Ford Foundation general counsel, US Trade Representative under Kennedy, counsel to the Ford family, and at the time partner in Dykema, Gossett, Spencer, Goodnow \& Trigg in Detroit; Orison Marden, partner in White and Case, former president of the NLADA and co-founder of the Legal Aid Society of New York City; Bernard Segal, a corporate lawyer in Philadelphia, former president of the ABA and former co-chair of the Lawyers Committee for Civil Rights Under Law; and Whitney North Seymour, partner in Simpson Thatcher, former president of the ABA, the Association of the Bar of New York City, and the Carnegie Endowment for Peace. As Hilbink notes, these lawyers unsurprisingly were committed opponents of radicalism and radical lawyers and believed that the system must be made to work better (337). Kalman in her study of Yale Law School in the 196os aptly notes that the creation of high-prestige, foundation-funded, public interest law firms provided an outlet 
to the graduates of Yale and other elite law graduates that, as she stated about Yale, allowed "students and professors alike to see themselves as both members of, and rebels against, the Establishment." (2005: 226).

Public interest law expanded dramatically in the 1970s and was followed by analogous investments in the global human rights movement by the Ford Foundation and others (Dezalay and Garth 2002). This was part of a retooling and revival of elite law consistent with the capital embedded in the liberal establishmentlarge corporations, philanthropic foundations, elite law schools, and the state (Kabaservice 2004). The relative complacency of elite law in the 1960s had led again to a potential period of "bust" and a challenge from within and without that ultimately was absorbed and contained. Elite corporate lawyers served on the boards of the public interest law firms, hired some former public interest lawyers, and helped elite lawyers regain some distance from their clients through the efforts of the public interest law firms. The pattern from the early twentieth century of elite processes of moderate reform tied to philanthropic foundations and corporate law firms had regained its credibility.

Legal theory in the relatively homogeneous law schools was consistent with the prevailing balance of power. Mark Tushnet's observation about constitutional legal theory in the 1970s is revealing in this respect: According to Tushnet, "the typical constitutional law article today has a standard form. The author identifies a doctrine developed in recent Supreme Court cases, notes some difficulties in the internal logic of the doctrine, indicates that the doctrine seems incompatible with the results of other cases, suggests minor modifications in the doctrine to make it consistent with those cases, and concludes that the doctrine as modified-almost uniformly into a balancing test-provides a sensible way of achieving results without going too far." In this way, according to Tushnet, the author manages in the end to show that the cases can be "embodiments of principles of justice, defined as the standard political principles of the moderate-left of the Democratic Party" (Tushnet 1979: 1322). This kind of homogeneity and complacency was part of what opened up the legal academy to challenge as well.

The story of continuity in academic legal theory from the New Deal into the 1970 is one of lawyers and law professors holding on to the places they had secured through legal realism and the collective mobility project of elite law professors. Elite constitutional law and legal theory from the leading law schools occupied that high-status space, with the interdisciplinary work of law and society being done mainly outside those spheres, but they all fit well within the "liberal legal establishment" and the project of moderate social reform. The challenge from the outsiders on the left had been contained and channeled into institutions where the elite corporate lawyers dominated.

\section{CHALLENGES FROM THE RIGHT}

The challenge from the right to the US position linked to the liberal establishment, the leading role of corporate law firms, and the position of corporate lawyers in 
politics and the state was both similar to and different from the one from the left. While the weakening credibility of the liberal establishment was important here as well, the challenge from the right came largely from outside the Ivy League and the Eastern establishment. It was initially led by conservative social movements and neoliberal economists. Part of the story involved the mathematicization of economics, which enhanced its legitimacy as a science and fostered the recognition of meritocratic entrants to the field. A related part was the rise of neoliberal economics centered in the University of Chicago economics department led by Milton Friedman. There was a social dimension to the movement. Chicagoans had an antagonistic relationship with the liberal establishment different from that of the insiders who had become antiwar and civil rights activists in the 1960s (Dezalay and Garth 2002). Chicago professors tended to view the ruling elite of the east coast in terms of "us against them."

The 1960 s reinforced this sentiment of exclusion in several ways. First, that period of economic growth had been credited to the Ivy League universities. Kennedy had invited the best-known Keynesians, in particular James Tobin and Paul Samuelson, to join his team of advisers. They recruited their students to Washington, where those students could gain more experience in setting economic policy. The Chicago outsiders' resentment with respect to the establishment that excluded them, despite their recognized scientific credentials, made the pioneers of pure economics the natural allies of those who promoted the conservative counterrevolution, which began to ascend in the 1970s (and included many businesses that felt that establishment organs-the New York Times and the Ford Foundation, for example-had become "antibusiness"). Second, they shared a hostility to the welfare state and-perhaps more importantly-to the Eastern establishment, which dominated the field of state power in part through its investments in the intellectual field. A learned counter-offensive-conducted under the banner of institutions such as the Hoover Institution, the American Enterprise Institute, the Heritage Foundation, and the Cato Institute-would provide these dominated theoreticians with the long-awaited opportunity to gain public recognition for their ideas.

James Buchanan, a disciple of Chicago who received the Nobel Prize for Economics in 1986 as the "father" of the new scholarship of public choice, contributed key theoretical tools for this counter-attack. Buchanan explicitly recognized his position of outsider, hostile to the establishment, as the source of his application of neoclassical economics to the analysis of political choices. His objective was to show that the holders of power were only following their own interests or those of the people who stood behind them. In addition to extending the imperialism of the neoclassical paradigm to new objects, this approach served to justify the postulates of the Chicago theoreticians who favored the market economy. The market could be justified as a way to avoid the inevitable rents associated with governmental intervention. Therefore, "in addition to providing a theoretical abstraction, public choice became a tool utilized above all to nourish and reinforce tactical arguments against monopolies, intervention, and state regulation" (Stone 1996: 156). 
The reactionary think tanks were the principal instrumental users of this theory. The interests of "pure theory" thus coincided perfectly with the antiestablishment strategy of the populist right, and one reason was that each side occupied a very similar position in the field of power. One of Buchanan's students recognized this connection as follows: "We were all heretics who were excluded from the academic world by the pure thinkers. . . . We had to make our way in policy circles instead. That's why so many of Jim Buchanan's students turned up in the Reagan administration" (Craig Roberts, in Warsh 1993: 96). Policy think tanks like the Heritage Foundation and the Cato Institute were also full of these "heretics." In this ideological counter-offensive, these "outsiders" skillfully managed to gain support through marketing and media campaigns.

The liberal establishment had staked its credibility on a gradual opening up to new groups that had been excluded from the centers of power in the United States. Corporate lawyers, philanthropic foundations, and the academy were central to this project. But the economics of the 1970s that went with the oil crisis, increased global competition, and challenges to corporate profits made corporate America and institutions such as the Wall Street Journal ready to embrace the neoliberal challengers and their scholarly theories and to take on the liberal establishment and the moderate activism it had come to embrace.

Law was considered to be on the side of the activist state and thus was viewed as a target rather than a potential ally. The Reagan administration had come to power fortified by a conservative social movement and a coalition of neoliberal economists and corporations determined to make Washington, D.C., more favorable to business. There were lawyers in the administration, of course, but legal expertise was not of any great importance except for the practical purposes of deregulation and an attack on legal activism. Richard Posner and other leading scholars in the field were quickly promoted to the bench during the first Reagan administration. But this largely reflected a negative strategy aimed at shrinking the state and deregulating the economy. These moves were not associated with the elite law schools, which were still overwhelmingly liberal (except for the University of Chicago) (Duxbury 1995). In the early stages of this movement, little value was assigned to lawyers and law, both seen as too close to the welfare state.

\section{THE PRODUCTION OF A "GOLDEN AGE" IN US LEGAL THEORY}

There is a perception that the 1980 os were a kind of golden age for legal theory in the United States (Hackney 2012) - a time when academic law played a major role in social debates. Law and Economics contended with Critical Legal Studies, Critical Race Theory, Law and Society, and Feminist Legal Theory, among others. From a sociological perspective, we can hypothesize some of the circumstances that produced this phenomenon. One was certainly an intensification of 
competition in academic scholarship within law, which related in part to the opening of the schools to more meritocratic entrants. Tenure standards tightened in law schools, and academic production became key to the growing lateral market in law professors.

Crucial to the story, however, was the political competition that fueled the academic production. The liberal establishment, despite efforts that responded to and contained the movements of the 196os and 7os, had not prevailed. It had lost a good part of its credibility as the strategy of social inclusion ran up against resource limits, economic crises, and the conservative backlash. The loss of credibility could be capitalized on by elite law professors importing critical theories from Europe (on Duncan Kennedy, see Hackney 2012: loc. 427). The legal scholars more generally offered competing theories to potentially connect with whatever political trend might next take over the country. Critical Legal Studies helped maintain the prestige and notoriety of the elite law schools and their professors with leftist critique-even though practitioners could essentially ignore it. Law and Society scholars thrived in part because they could maintain their alliances with dominated social groups, their commitment to social science technology (on Austin Sarat, see Hackney 2012: loc. 1986), and their defenses of the social state. The right's ascendant political movement directly against the liberal establishment found a place in the legal academy as "Law and Economics," which gained increasing influence in the 1980 s.

\section{CONSOLIDATING THE POWER OF THE RIGHT AND REBUILDING THE LEGAL ESTABLISHMENT}

The continuing vitality of much of the liberal establishment into the 1970s, despite the criticisms leveled at it, meant that the initial legal policies of the Reagan administration aimed at "defunding the left" to the extent it was embedded in law. As Steven Teles (2008) noted, "the most obvious strategy available to Reaganites for dealing with the organizational imbalance between legal liberals and conservatives was a vigorous attack on the financial foundation of liberal public interest law" (57). The Reaganites tried to take on public interest law and the Legal Services Corporation as one part of the strategy, but the legal establishment kept these programs alive. Another part of the Reagan program involved attacking "activist judges." At that point, indeed, elite law both within and outside the legal academy and the corporate bar was not on the side of the Reagan administration, and the conservative movement did not embrace elite lawyers and legal strategies. Teles labeled the situation "Grassroots without Elites: The Conservative Legal Movement Circa 1980" (57).

Put another way, as a parallel to the 1960s, the political activism of this timeconservatism-distrusted elite lawyers, whom it identified with a status quo it opposed. As Ann Southworth (2008) points out, it is indicative that "several 
lawyers talked about their unsuccessful battles to persuade their law firms to allow pro bono work for conservative causes" (120). The corporate law firms close to business clients did not even recognize the legitimacy of public interest law on the right. The legal establishment led by corporate lawyers was still one-sided in terms of its public service.

A key figure in remedying this was Michael Horowitz, a conservative, Yaleeducated lawyer. Illustrating the strength of elite school ties, Horowitz was invited by his liberal Yale classmate, Charles Halpern, to a symposium on public interest law (Teles 2009: 64). Horowitz noted the ways in which those in government and those in public interest law firms worked in "profoundly collusive ways, where the government agencies would lose and the court would order expansion of government programs, in a sense mandating appropriations that Congress was refusing to give.... When I was at Charlie's conference, here were these general counsels of agencies saying my door is always open to the Environmental Defense Fund, and we plot and scheme.... We work it out. You make these radical demands on me and then I can look like I'm in the middle. So we can advance the ship that way.... I thought that was a wonderful model" (64).

Horowitz wrote a report for the Scaife Foundation just prior to Reagan's election. It was a strong attack on what then existed as conservative public interest law. Interestingly, liberal scholars now trace the rise of public interest law and aggressive legal strategies on the right to a memorandum that Lewis Powell, soon to become a Supreme Court Justice, wrote in 1971 to the US Chamber of Commerce. Among other things, he called for more investment in learned legal strategies to counteract the liberal legal establishment. Activist websites today state, for example, that "the Powell Memo was the precipitating event for the swift rise and astounding success of big business and its control of the United States, starting in the early 1970s. The memo presented a bold strategy for how the corporate law firm could take over the key portions of the system, without the other side knowing what was happening" (Thwink.org 2006).

As Schmitt (2005) noted, however, the Powell memo was not really discovered until 1993, after the legal counter-revolution had essentially succeeded: "Most histories of the right don't attribute any significance to the Powell Memo at all. Indeed, a biography of Powell ... doesn't discuss it" (2). That memorandum was a pitch to broaden the legal establishment and promote more business-friendly rhetoric, but it was not very important at the time because the legal establishment was essentially irrelevant at that time to the conservative agenda.

Horowitz's report on public interest law attacked the existing conservative public interest law firms in part for the "privileged role of business in the movement," suggesting that they gave the appearance of being "nothing more than shills for conservative business interests" (Teles 2009: 68). Business funding did not help. The funding, he argued, should be mainly from the conservative foundations. They also needed to distance themselves from "party politics," and perhaps above 
all, they needed to recruit elite "idealists" and speakers "for such unrepresented parties as taxpayers, ultimate consumers, and small businesses" (69). Accordingly, they needed to recruit law clerks, law review leaders, and graduates from the most elite schools, who would be inspired by ideas and by standards of professionalism. They needed to develop close ties to the elite law schools and legal scholarship.

Horowitz joined the Reagan administration himself, but in the early days of that administration, he stated, it was difficult to find ideologically committed lawyers with elite credentials. According to Teles, "these were the days before the Federalist Society was really off the ground, so it was hard to find lawyers who had a conservative political outlook" (69). They were not just missing from public interest law. They also were not in the law schools or in the large corporate law firms. The legal establishment contained only a few conservatives at the time.

Key to the change that followed was a strategy of aggressive recruitment developed under Attorney General Edwin Meese during the second Reagan administration. After that administration, many more elite lawyers were available to move into the elite legal academy and the conservative public interest law firms, there were respectable scholarly theories for lawyers on the right, there were openings for conservative pro bono in large law firms, and it was easy to find conservatives who were "the next generation of Lloyd Cutlers and Joe Califanos who are prepared to run law firms and to assume major government positions" (Southworth 2008: 39).

Horowitz made a similar point about his work recruiting into the administration: "[I acted] as a career mentor and someone who encouraged people to come into government, or not to stay too long and go back into private practice and earn a source of independent income so that they would not be government junkies all their lives ... to approximate the model of the Clark Cliffords and Cy Vances and Califanos and the others to move from their law firms back to cabinet secretaryships back to their law firms" (Teles 2009: 72). Horowitz quite clearly embraced the model of the lawyer-statesperson at the top of the legal hierarchy, but he wanted a place for political conservatives playing the same role as the liberals had in the past. Drawing on the same set of elite institutions-law firms, public interest law firms, foundations, law schools-that had sustained the liberal establishment, coupled with an alliance with neoliberal economists, he set out to rebuild the place of elite lawyers in the competition to produce solutions to social problems and enact the agenda of the newly configured establishment.

\author{
POSITIVE LEGAL THEORY, THE FEDERALIST \\ SOCIETY, AND THE NEW CONSERVATIVE LEGAL \\ ESTABLISHMENT
}

Meese and Horowitz embraced the Federalist Society to build their recruitment. The Federalist Society provided a group of young and ambitious law professors 
seeking to retool legal scholarship in alliance with the emerging political right-a version of the classic Berman formula for legal revolution. The Federalist Society had been established by Yale College graduates attending elite law schools in the early days of the Reagan era. They were acutely aware that liberals dominated those schools. These law students teamed up with the few famous conservatives close to the elite legal world, including Robert Bork and Antonin Scalia. Meese then recruited from among the few conservative legal academics, such as Gary McDowell and Federalist Society founders Steven Calabrese, David McIntosh, and Lee Liberman Otis, and focused on long-term scholarly thinking and planning.

At this point, finally, legal academics and legal theory entered the picture. One of the Federalist Society projects was to develop "originalism" as a constitutional theory. Originalism provided a legal theory-not just a political program-that helped secure prominent places in elite law schools for legal conservatives, and from those prominent positions they could provide tools for elite conservative lawyers and judicial allies to legalize the politics of the right (Hollis-Brusky 2015). There was a huge investment in the new legal theory. As Hollis-Brusky notes, the legalizing of the conservative agenda was quite remarkable:

Law and Economics, Natural Law Jurisprudence, and Originalism-as recently as the early 1980s these strands of conservative and libertarian legal thought were considered by most in the American legal profession to be "off the wall" or, as Jack Balkin has more colorfully described them, "positively loony." ... Within the span of two short decades, however, these ideas came to be accepted as "positively thinkable" and to being practiced as "good legal craft." ... Each year, several hundred articles espousing these theories appear in the pages of the most respected law journals in the country, and these same ideas have been drawn upon by federal judges and Supreme Court justices to articulate some of the most important judicial decisions of the last fifteen years. (Hollis-Brusky 2011: 521)

Meese and his team thus connected with a heretofore marginal legal group and brought them into the core of the Reagan administration and the conservative political movement. They drew conservative law students into the same mindsetdo they choose elite corporate law, government, or elite public interest law? - that liberal law students faced. One measure of their success is that conservative public interest law firms became one component of the academic, corporate law firm, and governmental strategy. Those coming out of the Reagan administration were perfect recruits, and "conservatives used strategic litigation to reshape perceptions that they were greedy, callous, captured by big business, and uninterested in the cause of racial justice" and also to "distance themselves from their existing constituencies" (Teles 2008: 279) - to serve them better in the long term.

Southworth examines what she terms the mediator organizations and the individuals within them, who serve as the core of this conservative legal establishment. They are the best-known individuals within the conservative legal community, and include Edwin Meese (who moved to the Heritage Foundation, symbolizing 
the move of elite law into the conservative policy movement once represented only by conservative economists), Ted Olson, and Kenneth Starr. Foundation money overwhelmingly goes to the groups associated with them rather than to other groups. Mediator groups also stress "the value of civility" (Southworth 2008: 81), as did the liberal legal establishment in the 1960s. They are "elite members of the broader legal establishment, concerned about maintaining their stature in that larger community and defending its values" (81). They defend one another regardless of politics (69). In addition, their connections to business and to corporate law ensure that neither conservative nor liberal law gets too out of touch with the corporate and financial communities.

The liberal legal establishment has shifted to absorb the neoliberal revolution, and that shift is well represented with the rise of behavioral law and economics, which is marketed as a supplement to neoliberal economics. The relatively more liberal, but still mainstream, economists who have pushed back on purer versions of neoliberalism, such as Joseph Stiglitz and Thomas Piketty, also offer ways for new legal theories to relegitimate a moderate social reform agenda in which elite lawyers can play a central role. The position of corporate law and allied public interest law is again relatively strong, now closely involved with both the liberal and the conservative establishments.

Elite law is divided, as is US politics, but elite law comes together within the key institutions of the legal field-law schools, the Supreme Court, corporate law firms (perhaps with some division of labor among more conservative law firms, such as Kirkland and Ellis, and more liberal ones, such as Arnold and Porter), and bar associations. The disagreements between the two sides mask the fact that both are closely connected to corporate power. The agreement extends also to certain issues of high profile for elites, such as gay marriage (Ted Olson and David Boies), and where elite corporate lawyers make common ground, such as when defending individuals detained at Guantanamo, disqualifying Supreme Court nominees who lack elite credentials, and a focus on the US Supreme Court as the key arbiter of politics (Southworth 2008). Indeed, making clear the pivotal role of the corporate bar today, Reuters published an article that reported that less than 1 percent of "lawyers who filed appeals to the Supreme Court" were involved in 43 percent of the decided cases between 2004 and 2012. And "of the 66 most successful lawyers, 51 worked for law firms that primarily represented corporate interests" (Biskupic, Roberts, and Shiffman 2014: 3).

\section{CHANGE AND CONTINUITY}

The rebuilding of the position of the legal elite in the United States is the culmination of the attack on the Eastern legal establishment from within and outside the institutions of the establishment. The story of today's divided elite is linked closely to the expansion of higher education in the 1950 s and 6os, which produced 
a generation with elite academic credentials but also aware of the glass ceiling they faced because they lacked the social pedigree of graduates of the Eastern prep schools and the dominant leaders of the FPE. Their activism helped produce the counter-attack on the right, which also relied to a great extent on scholarly and meritocratic capital-beginning with neoliberal economics mobilized against the Eastern establishment of Keynesians anchored at Harvard and Yale.

The forces that brought about the conservative counter-revolution also fought on behalf of scholarly capital, especially neoliberal economics but also Critical Legal Studies and Originalism, against the mix of scholarly and inherited capital that had dominated the state since Franklin Roosevelt in support of the liberal establishment. The next part begins with a discussion of how law and development efforts abroad changed with respect to shifts within the United States. The first chapter in Part IV then discusses India, which in many ways is in between the two approaches to law and development emanating from the United States. On one side is the idealism of public interest law and retooled lawyer-statespersons; on the other is the powerful extension of the neoliberal revolution into the center of the legal field. 